\title{
Effects of Youth Employment Policies on Employability in the Congo
}

\author{
Fabien Constantin Lekouka, Rolande Iphigénie Menga Mokombi \\ Faculty of Economics, Marien Ngouabi University, Brazzaville, Congo \\ Email: fablekouka@gmail.com
}

How to cite this paper: Lekouka, F. C., \& Mokombi, R. I. M. (2021). Effects of Youth Employment Policies on Employability in the Congo. Modern Economy, 12, 1929-1948. https://doi.org/10.4236/me.2021.1212101

Received: November 4, 2021

Accepted: December 20, 2021

Published: December 23, 2021

Copyright $\odot 2021$ by author(s) and Scientific Research Publishing Inc. This work is licensed under the Creative Commons Attribution International License (CC BY 4.0).

http://creativecommons.org/licenses/by/4.0/

\begin{abstract}
This article analyzes the effect of public employment policies on the employability of young people in the Republic of the Congo. An ordered multinomial logit model with correction for selection bias was used on survey data regarding the improvement of youth employment policies in French-speaking Africa carried out in 2018 in the Republic of the Congo. The results show that participation in the employment program improves the employability of young people in the Republic of the Congo but that its effects are limited. Similarly, beyond the effects of employment policies on employability, variables such as sex, age, marital status, religion, and enrollment in the Office National de l'Emploi et de la main-d'Oeuvre (ONEMO), currently the Agence Congolaise Pour l'Emploi (ACPE), influence participation in employment programs in the Republic of the Congo. These results give rise to implications for economic policy.
\end{abstract}

\section{Keywords}

Employment Policy, Employability

\section{Introduction}

Faced with high and persistent unemployment in Africa, the implementation of a new generation of public policies in favor of employment seems necessary according to the International Labor Organization (ILO, 2019). Indeed, according to an ILO (2019), African countries recorded nearly 34 million unemployed individuals in 2019 compared to 20 million in 2010, i.e. 14 million more. This situation is more important for young people, among whom there are more than 12 million aged 15 to 24 years who were unemployed in 2019 compared to those in 2010 (ILO, 2019).

In Central Africa, the number of unemployed youths aged 15 to 24 increased 
by almost one million in 2019 compared to 2010, when the number of unemployed youths was approximately 2 million (ILO, 2020). This increase has led most countries to implement constructive macroeconomic policies, thereby contributing to positive economic growth (Wohlmuth et al., 2021). Despite, the increase in economic growth recorded in these countries, macroeconomic policies in general and employment policies, in particular, have not contributed much to the improvement of the labor market situation of young people.

In view of this outlook for the labor market in Central Africa, it would be difficult for these countries to achieve the objective outlined in Agenda 2063, which is in line with goal eight (8) of the Sustainable Development Goals (Adams, 2017), which consists of the promotion of youth employment, education and training by 2030 by African governments. To this end, the consideration of macroeconomic policy reforms in general and public employment policies for young people in particular, which, focus on improving their level of employability, is a way to address the problem of youth unemployment (ILO, 2014, 2010; Kasekende \& Brownbridge, 2011).

To this end, Republic of the Congo has initiated several employment programs during the period from 2000 to 2019, supported by the National Development Plan (NDP) 2018-2022 (African Development Bank, 2018). Despite these efforts to improve employment in general and youth in particular, the unemployment situation remains a major challenge, especially among young people aged 15 - 29 (30\%) (African Economic Outlook, 2018).

Moreover, the Survey on the Improvement of Employment Policies in the Congo (EAPE), which was conducted in 2018 showed that the youth unemployment rate represents nearly $32 \%$ and $16 \%$, in Pointe-Noire and Brazzaville, respectively. Similarly, the Congolese labor market is faced with a downgrading situation since $29.05 \%$ of young people have been downgraded (EAPE-C, 2018). In view of the above information, it can be observed that the implementation of these policies seems to be less effective in resolving employment issues in the Congo. This lack of effectiveness justifies the importance of this research on the analysis of youth employment policies and employability in the Congo.

In the economic literature, the effects of public employment policies on the employability of young people are controversial at both the theoretical and empirical levels. At the theoretical level, the analysis of the effects of public employment policies on the employability of young people has developed around three approaches: The first approach presents public employment policies as a means by which to improve the ability of applicants to obtain a job (Charlot, 2005; Dufour \& Frimousse, 2006). The second approach, which is based on the theory of professional insertion, explains this relationship by evoking the idea that public employment policies developed in collaboration with companies help to reduce the duration of unemployment for young beneficiaries (Hicks, 1932; Pigou; 1933). The last approach revolves around the hypothesis that public employment policies promote the construction of social networks between appli- 
cants and company managers (Granovetter, 1973).

At the empirical level, the work of Makosso (2013) on entrepreneurship in the Congo showed the existence of a strong relationship between business creation and unemployment. According to this study, if unemployment increases by $10 \%$, then the number of businesses created increases by $19.23 \%$. Similarly, the work of Ndinga et al. (2020) showed that public employment policies have an effect on the access to employment of young people in the Congo. The work proposed in the Republic of the Congo regarding the issue of employment is limited to problems related to access to employment and youth entrepreneurship on the one hand (Ngassa, 2018; Makosso, 2013) and the relationship between public employment policies and their effect on access to employment on the other hand. Few studies have addressed the question of the effects of public employment policies on the employability of young people in the Congo.

The resolution of this problem can help to reveal the importance of the relationship between public employment policies and the educational system in the Congo. In the Congo, the issue of the adequacy between the education system and the labor market is opposed with acute closeness; according to the results of ETVA-2015, nearly $52.1 \%$ of young workers are underqualified; while $41.4 \%$ feel inadequate with their level of training. Similarly, the results of the EAPE-C survey, which was conducted in 2018, show that the mismatch between training, education and employment is a source of downgrading. In view of the above, only one question can be asked: What are the effects of public employment policies on the employability of young people?

The main objective of this study is to analyze the effects of public employment policies on employability in the Congo. Thus, in this work, we support the hypothesis that public employment policies improve youth employability.

This work is structured in five (5) sections. In addition to the introductory section, the second section is devoted to the literature review. The methodology is the subject of the third section. The fourth section deals with the presentation and interpretation of the results obtained. The fifth section is devoted to the conclusion and the implications of the suggested policies.

\section{Literature Review}

The debate on the effects of public employment policies in the economy can be structured around three main approaches. The first approach revolves around the idea that public employment policies increase the ability of beneficiaries to obtain a job through improved employability (Charlot, 2005). This thesis is supported by the idea that investment in human capital must be continuous for job seekers; therefore, it improves the employability of young job seekers. This idea highlights the relationship between public employment policies and the education system; it implies that public employment policies influence employability through the human capital dimension of job seekers' education (Dufour \& Frimousse, 2006). 
This approach has been the subject of several works (Dufour \& Frimousse, 2006; Thiaw, 2020; Ndinga et al., 2020), which have revealed the existence of a positive relationship between public employment policies and the employability of young job seekers based on education. The study of Dufour \& Frimousse, (2006), evoked the hypothesis that at the end of the school system, young people with a low level of education present difficulties related to finding a job. Hence, the transition to an employment program improves access to a job, i.e., increases the employability of beneficiaries (Gasquet, 2002). Moreover, the study by Thiaw (2020), of the case of Senegal; investigated the relationship between employment policies and skills in the labor market. Using data from the Senegal Poverty Monitoring Survey (ESPS II) conducted in 2011; this study was conducted using the multinomial logit model; the author arrived at the result that there is a significant and positive relationship between human capital and the probability of access to employment for young people. Therefore, it can be concluded that employment policies improve the level of employability. Similarly, Ndinga et al. (2020) used an ESR model estimated by the method of maximum likelihood with compete information, obtained the results, showing that, on average, one out of two young people who participate in PPE gain access to a job. To this end, the different results obtained in this approach suggest the important role of harmonization between public employment policies and the education system.

The second approach revolves around the hypothesis that public employment policies that are developed in collaboration with companies reduce the duration of unemployment of young beneficiaries of these policies. This approach is based on the positive relationship that exists between the theory of professionals (Hicks, 1932; Pigou, 1933) and the theory of human capital (Becker, 1964). Indeed, according to Becker (1964), there are two main sources of knowledge acquisition, namely, training on the job and training through school which corresponds to the individual's initial training. The main idea of this approach is that public employment policies through subsidies to companies, favor the creation of jobs in the labor market and the integration and non-dismissal of young people (Gautié, Gazier, \& Silvera, 1994; Chapple et al., 1996). Similarly, policies related to bonuses for young trainees allow job seekers who receive financial bonuses to reduce their period of unemployment simply because they were chosen to participate in the experiment (Meyer, 1995). According to this logic, the presence of young applicants in the company helps develop their employability and contributes to the company's performance (Ben Hassen, 2011; Saint-Germes, 2004).

As a result, several studies have shown that on-the-job training increases the employability of young people. Among these studies, there is the job-related work of Crépon, Duflo, Gurgand, Rathelot and Zamora (2013), which showed that search support policies have very significant effects between treatment and control groups; this work used matching methods. Similarly, in the case of Côte d'Ivoire, Kouakou (2011) examined the relationship between active employment policies and youth employability in the city of Abidjan using a Weibull-type du- 
ration model with instrumentation. This study showed that employment programs have significant effects on the exit of youth from unemployment. In addition, the work of Magnac $(1997,2000)$ evaluated the effects of paid internships on the employment stability of French youths aged 18 to 29 using a multinomial logit model. Overall, the results showed that paid internships have little effect on groups experiencing difficulties integrating into the labor market, particularly young women and young people from families in which the initial educational capital is low. On the other hand, the study by Magnac (1997) used the effect of training courses in favor of young people. The author used a panel of the 1990, 1991 and 1992 employment surveys and the 1992 complementary youth survey from the INSEE supplementary survey of young people in France. He useds a model of transitions between states from one period to the next that took into account unobservable heterogeneity to estimate the impact of the internships. The variable of interest was the ease of transition from internships to different states (CDI, CDD, unemployment, education, inactivity). The results obtained showed that employment policies do not have significant effects on the integration of young people.

The third approach revolves around the hypothesis that public employment policies promote the construction of social networks (Granovetter, 1973). This approach puts forward the theory of self-determination, which refers to the idea that public employment policies develop the need for social belonging for beneficiaries within reception structures (Deci \& Ryan, 1995). Economic theory states that employability depends on several factors among which are relational factors (Béduwé \& Mora, 2017; Van Der Heijden, 2006). To this end, employment policies also develop an individual's sense of belonging to society or social capital (Loufrani-Fedida \& Saint-Germes, 2015; Zgoulli et al., 2016). This approach leads to the conclusion that public employment policies help to expand the network of young job seekers. Empirically, many studies have highlighted the effects of public employment policies on the employability of young people from the aspect of social capital improvement. The study by Kloman-Kouakou et al. (2020) was conducted from the database of the CREMIDE-CRDI survey conducted in 2017-2018 in Côte d'Ivoire. The results obtained from a generalized Tobit model of type 2 , showed that social capital favors obtaining a job but negatively influences wages.

From the literature presented above, two lessons can be suggested. The first lesson is related to the problem of bias (selection and endogeneity) in the participation of young people in the employment program. Indeed, at this level, the results obtained remain controversial and vary according to the methods and fields of study (Kloman-Kouakou et al., 2020; Ndinga et al., 2020; Thiaw, 2020). Indeed, the use of analytical tools recently developed through the various works of (Magnac, 1997; Thiaw, 2020); in the consideration of the problem of selection bias from the two-stage estimation method of Heckman, extended to the case of several alternatives (Torns, 1995; Maddala, 1983; Dubin \& McFadden, 1984) seems important in the case of Republic of the Congo. The use of this methodo- 
logical approach constitutes an empirical contribution in the case of developing countries in general and Republic of the Congo in particular.

The second lesson concerns the existence of factors favouring the effects of employment programs on youth employability (human capital, social capital). Rare are the works that analyze the question of the effects of youth employment programs on the employability of young people by taking into account these factors (human capital and social capital). Thus, this work, which focuses on the analysis of the effect of public employment policies on the employability of young people in Republic of the Congo, places particular emphasis on these factors. The consideration of these factors in this article constitutes a contribution to the literature on the analysis of the effect of public employment policies on youth employability in developing countries.

\section{Methodology}

This section is structured in three main points. The data and construction of the employability indicator will be the subject of the first point, the second point will present the methodological approach and the last point will present the estimation results and discussion.

\subsection{Data and Construction of the Employability Indicator}

\subsubsection{Data}

The data used, in this work, come from the 2018 EAPEC database. This database was compiled by IDRC and LARES via the Employment Policies Survey. The sample is made up of 3000 individuals aged 15 - 34 (belonging to Brazzaville and Pointe-Noire). The use of this database is important not only because it is recent but also because it makes it possible, through the household and individual questionnaires of young people, to grasp the situation of young people who participated in the employment program.

Indeed, the treatment of missing data was done using the deductive imputation method (Kalton et al., 1983), which consists of deducing the missing data from the other questions by checking the consistency of the answers to the related questions.

\subsubsection{Construction of the Employability Indicator}

The concept of employability appeared at the beginning of the 20th century. This concept basically refers to the capacity to be employed, which often translates into the probability of an individual holding a job (Cart \& Toutin, 1996). In fact, the measurement of employability is based on three fundamental elements (Hillage \& Pollard, 1999). These elements can be defined as the ability to obtain initial employment as conditioned by the educational system, among other things; the ability to keep one's job and to make transitions between jobs and roles in the same organization; and the ability to find another job, if necessary, which is as understood as the ability and willingness of individuals to manage job transitions between organizations and within them (Finot, 2000). 
The construction of the employability level indicator required the use of the multiple correspondence analysis (MCA) methodology. Following Benzécri's proposition cited by Cahuzac (2008), we discriminated by keeping only the eigenvalues that were higher than the average eigenvalue. This led us to retain only two (02) factor axes in the execution of the ACM (while creating the indicator with the unclassified observations). After the ACM, an ascending hierarchical classification $(\mathrm{CAH})$ was performed to create homogeneous groups. This process was followed by the generation of the Composite Employability Indicator (ICE) with four (04) homogeneous groups. That is, "very low employability", "low employability", "average employability" and "high employability".

The dimensions chosen for the construction of the employability indicator were established by the work of Finot (2000); and Roger (2004). These authors define employability by referring to skills, creativity and organizational capacity. Table 1 essentially presents the dimensions and variables that were used to construct the employability indicator (ECI).

\subsection{Methodological Approach}

The objective of this article is to analyze the effects of employment programs on the employability of young people. In the economic literature, some studies have

Table 1. Variables for the calculation of the composite indicator of employability (ICE).

\begin{tabular}{|c|c|c|c|}
\hline Dimensions & Variables & Analyze level & Employability threshold \\
\hline Labor market type & $\begin{array}{c}\text { Status in the labor } \\
\text { market }\end{array}$ & Individual & $\begin{array}{l}\text { Threshold: the person is } \\
\text { employable if he or she is } \\
\text { considered old in the } \\
\text { labor market. }\end{array}$ \\
\hline Employment & $\begin{array}{c}\text { Duration of } \\
\text { unemployment }\end{array}$ & Individual & $\begin{array}{l}\text { Threshold: the person is } \\
\text { employable if they are } \\
\text { unemployed for at least } \\
\text { six months. }\end{array}$ \\
\hline Human capital & Education & Individual & $\begin{array}{l}\text { Threshold: the person is } \\
\text { employable if he or she is } \\
\text { at least a member of an } \\
\text { association. }\end{array}$ \\
\hline Share capital & $\begin{array}{c}\text { Militant religion } \\
\text { NGO }\end{array}$ & Individual & $\begin{array}{l}\text { Threshold: the person is } \\
\text { employable if they are at } \\
\text { least a member of an } \\
\text { association. }\end{array}$ \\
\hline Health & Health & Individual & $\begin{array}{l}\text { Threshold: the person is } \\
\text { employable if they are in } \\
\text { good health }\end{array}$ \\
\hline Offer & $\begin{array}{l}\text { Knowledge of } \\
\text { employment } \\
\text { structures }\end{array}$ & Individual & $\begin{array}{l}\text { Threshold: the person is } \\
\text { employable if they are } \\
\text { registered with ONEMO. }\end{array}$ \\
\hline
\end{tabular}

Source: Authors based on existing literature and the 2018 APE-C database. 
used probit and logit models to analyze the effects of public employment policies (Magnac, 1997; Issehnane, 2009). In addition, other studies haves used experimental models to evaluate the impact of policies (Kouakou, 2011; Ndinga et al., 2020). In the case of this article, we will focus on the use of an ordered logit model with selection bias correction.

\subsubsection{Theoretical Framework of the Ordered Logit Model}

Introduced by McFadden in 1968, the multinomial logit model makes it possible to study the possibility that an individual can make a choice from among several possibilities. Theoretically this type of model is based on the notion of preference i.e., the variable to be explained represents the possibilities of choice of an among several possibilities, which is called the random utility model. Thus, the choice of the individual $Y_{i}=J$ is retained if $U_{i i}=\max \left(U_{i n}, U_{i 1}, \cdots, U_{i M}\right)$.

It is assumed that each individual $i$ has to choose one possibility from among the $n$ possibilities. To this end, we seek to study the single decision of an individual among a number of ordered alternatives. In an ordered choice model, individual $i$ will compare the different levels of utility associated with the various choices, and then choose the one that maximizes his utility among the $J$ choices. For individual $i$, the utility of choice $j$ is as follows:

$$
U_{i j}=\delta Y_{i j}+\varepsilon_{i}
$$

\subsubsection{Specification of an Ordered Logit Model}

To analyze the effects of public employment policies on employability, we drew on the work of Thiaw (2020), who categorized employability on a scale ranging from very low employability to high employability. This can be written as follows:

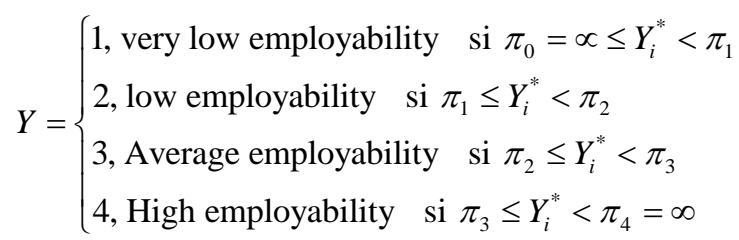

The model specification is as follows:

$$
Y=\varepsilon+\beta X_{i}+\mu_{i}
$$

where $\beta$ is a vector of parameters to be estimated, $X_{i}$ is a vector of the socioeconomic characteristics of participants $i \mu_{i}$ is an error term distributed according to a logistic law and $Y_{i}^{*}$ is an unobserved latent variable.

The observed probability for the values of $X$ is given by:

$$
\operatorname{Pr}(y=m \mid X) \operatorname{Pr}\left(\pi_{n-1} \leq Y_{i}^{*}<\pi_{n} \mid X\right)
$$

Substituting $Y_{i}^{*}=\varepsilon+\beta X_{i}+\mu_{i}$ in the expression of this probability, we end up with the standard formulation for the predicted probabilities in the ordered regression model, i.e.:

$$
\operatorname{Pr}(y=m \mid X) F\left(\pi_{n}-\beta X\right)-F\left(\pi_{n-1}-\beta X\right)
$$

where $F$ is the distribution function of $\mu$. In the ordered probit, $F$ is normal with 
$\operatorname{Var}(\mu)=1$ while in the ordered logit, $F$ is logistic $\operatorname{Var}(\mu)=\frac{\pi^{2}}{3}$.

The correct assessment of the role of the explanatory variables is made from the marginal effects. These effects are obtained through the following expressions:

$$
\begin{gathered}
\partial \operatorname{Prob}(y=0 \mid X) / \partial X=-f\left(X^{\prime} \beta\right) \beta \\
\partial \operatorname{Prob}(y=1 \mid X) / \partial X=\left[f\left(-X^{\prime} \beta\right)-f\left(\tau-X^{\prime} \beta\right)\right] \beta \\
\partial \operatorname{Prob}(y=2 \mid X) / \partial X=\left[f\left(\tau-X^{\prime} \beta\right)\right] \beta
\end{gathered}
$$

The marginal effects when $\operatorname{Prob}(y=0 / X)$ are always of the opposite sign of $\beta$. By the same logic, the marginal effects in the other two cases are in the same direction as the sign. Since the sum of the three probabilities is equal to unity, the sum of the marginal effects is equal to zero. It is therefore sufficient to present two of the marginal effects to deduce the last.

The process of estimating an ordered logit makes it possible to model the assessment of the level of employability as follows: very low employability, low employability, average employability and high employability. Similarly, the use of Heckman's two-step estimation method, as extended to the case of several alternatives (Torns, 1995; Maddala, 1983; Dubin \& McFadden, 1984), will make it possible to resolve the problem of selection bias related to participation in the employment program. Thus, the first step of the empirical analysis will be to estimate the probabilities of choosing to participate in the different programs. This will make it possible to construct Mills' ratios which are used in the second stage as additional explanatory variables in the employability equations. These new corrected equations are then estimated using the maximum likelihood method.

\subsubsection{Description of Variables}

Empirical work on the question of the effects of public employment policies has developed several variables; among which we have: marital status. This variable significantly influences the labor market, as being married is a determinant of the behavior of individuals (Spierings et al., 2008). Similarly, household size and having a child affects the labor market behavior of young people (Samuel et al., 2012). Indeed, the work of Ndinga et al. (2020) and Ngassa (2018) has shown that social capital is a determinant of access to employment. Moreover, Kolev and Fluitman (1989) proved that the level of education has an effect on access to employment.

The analysis of Table 2 shows that approximately $71.53 \%$ of the young people who participated in the employment program in the Republic of the Congo have a very low level of employability. On the other hand, $10.95 \%$ of the population in our sample has a high level of employability. This is due to the fact that most of the employment programs in the Congo focus on early school leavers. Similarly, the gender results show that participation in the employment program seems to be skewed toward men. This finding is corroborated by the fact that the proportion of men who participate in the employment program (86.86\%) is higher than 
Table 2. Profile of participants and nonparticipants in the employment program.

\begin{tabular}{|c|c|c|c|c|}
\hline & \multicolumn{4}{|c|}{ Participation in the employment program } \\
\hline & \multicolumn{2}{|c|}{ Yes } & \multicolumn{2}{|l|}{ No } \\
\hline & Workforce & $\%$ & Workforce & $\%$ \\
\hline \multicolumn{5}{|l|}{ Employability } \\
\hline Very low employability & 98 & 71.53 & 649 & 32.21 \\
\hline Low employability & 20 & 14.60 & 432 & 21.44 \\
\hline Average low employability & 4 & 2.92 & 418 & 20.74 \\
\hline High employability & 15 & 10.95 & 516 & 25.61 \\
\hline \multicolumn{5}{|l|}{ Place of residence } \\
\hline Brazzaville & 35 & 25.55 & 603 & 29.93 \\
\hline Pointe Noire & 1412 & 70.07 & 102 & 74.45 \\
\hline \multicolumn{5}{|l|}{ Sexe } \\
\hline Male & 119 & 86.86 & 1288 & 63.92 \\
\hline Feminine & 18 & 13.14 & 727 & 36.08 \\
\hline \multicolumn{5}{|l|}{ Registration with the employment } \\
\hline Yes & 1628 & 80.79 & 121 & 88.32 \\
\hline No & 387 & 19.21 & 16 & 11.68 \\
\hline \multicolumn{5}{|l|}{ Education } \\
\hline No level & 217 & 10.77 & 19 & 13.87 \\
\hline Has a level & 1798 & 89.23 & 118 & 86.13 \\
\hline
\end{tabular}

Source: Authors based on APE-C database, 2018.

that of women (13.14\%). In addition, participation in the employment program is more interesting for those who have knowledge of ONEMO (80.79\%) than for those who do not have knowledge of ONEMO (19.21). ONEMO. These different points justify the need to analyze the effects of employment programs on the employability of young people.

Table 3 of the descriptive statistics of the different variables above give the central tendencies of the different variables retained in the empirical models of this study.

\subsection{Econometric Results and Discussion of the Results}

This section will first deal with econometric results and then discuss the results obtained after the estimations are made.

Presentation of Econometric Results

The results in Table 4 reveal that participation in the youth employment program is influenced by several factors. Indeed, the overall quality of the model 
Table 3. Descriptive statistics on the variables.

\begin{tabular}{|c|c|c|c|c|c|}
\hline Variables & Observations & Mean & Std. Dev. & Min & $\operatorname{Max}$ \\
\hline Employement Program & 2152 & & & 0 & 1 \\
\hline Sexe & 2152 & & & 0 & 1 \\
\hline Age & 2152 & 27.331 & 7.776 & 15 & 35 \\
\hline Age $2 / 100$ & 2152 & 8.074 & 7.658 & 2.25 & 12.25 \\
\hline Marital Status & 2152 & & & 0 & 5 \\
\hline Religion & 2152 & & & 0 & 6 \\
\hline Heath status & 2152 & & & 0 & 1 \\
\hline Education & 2152 & & & 0 & 1 \\
\hline Registration with the l'ONEMO & 2152 & & & 0 & 1 \\
\hline Place of residence & 2152 & & & 0 & 1 \\
\hline Unemployment Duration & 2152 & & & 0 & 1 \\
\hline Training Area & 2152 & & & 0 & 1 \\
\hline Household size & 2152 & 5.01 & 7.523 & 0 & 16 \\
\hline $\begin{array}{l}\text { Distance between your home } \\
\text { and the employment office }\end{array}$ & 1385 & & & 1 & 7 \\
\hline
\end{tabular}

Source: Elaborated from data from EAPE-C (2018).

Table 4. Results of the probit model and marginal effects of the employment program participation equation.

\begin{tabular}{ccc}
\hline Participation in the employment program & Coefficient & $\mathrm{dy} / \mathrm{dx}$ \\
\hline Sex & $0.582^{* * *}$ & $0.067^{\star * *}$ \\
Age & $(0.11)$ & $(0.013)$ \\
& $0.198^{* *}$ & $0.023^{* *}$ \\
Age2 & $(0.081)$ & $(0.009)$ \\
& $-0.321^{\star *}$ & $-0.037^{\star *}$ \\
Marital status & $(0.148)$ & $(0.017)$ \\
& & Ref: Single \\
Common-law union & 0.039 & 0.005 \\
& $(0.107)$ & $(0.013)$ \\
Separate & $0.496^{*}$ & $0.079^{\star}$ \\
& $(0.300)$ & $(0.062)$ \\
Divorced & 0.556 & 0.092 \\
Widower & $(0.416)$ & $(0.091)$ \\
Married & - & - \\
& -0.378 & -0.033 \\
& $(0.325)$ & $(0.021)$ \\
\hline
\end{tabular}




\section{Continued}

\section{Religion}

Protestant

Other Christian

Muslim

Animist

Other religion

No religion

State of health

Bad condition

Education

No Level

Registration with the ONEMO

Yes

Place of residence

\section{Brazzaville}

Unemployment duration

less than 6 months
Constant

Ref: Catholic

$-0.105$

$-0.012$

(0.131)

(0.015)

$-0.109$

$-0.012$

(0.105)

(0.012)

0.382

0.060

(0.347)

(0.067)

$-0.126$

$-0.014$

(0.361)

(0.037)

$0.500^{\star * *}$

$0.085^{\star * *}$

(0.182)

(0.038)

$-0.161$

$-0.018$

(0.489)

(0.048)

Ref: Good condition

$$
-0.127 \quad-0.015
$$

Ref: Have a level

$$
\begin{array}{ll}
-0.277 & -0.032 \\
(0.201) & (0.023)
\end{array}
$$

Ref. No

$$
\begin{array}{cc}
-0.391^{\star * *} & -0.045^{\star * *} \\
(0.152) & (0.018)
\end{array}
$$

\section{Ref. Pointe-Noire}

$-0.05 \quad-0.006$

(0.107)

Ref. more than 6 months

$$
-0.061 \quad-0.007
$$

$\mathrm{N}=2151$. Wald chi1 $(18)=82.2$. Prob $>$ chi2: 0.000 . pseudo $\mathrm{R}^{2}=0.079$. Log pseudo $=-469.07$

Notes: SE in brackets ${ }^{* * *} p<0.01,{ }^{* *} p<0.05,{ }^{\star} p<0.1$, Source: Elaborated from data from EAPE-C (2018).

estimate is good, and the chi-square of the model is 81.172 and significant at the $1 \%$ level. The pseudo-R squared is 0.079 . Similarly, the results in Table 5 show that the variable of Pmr controls for the selection bias associated with participation in the employment program. Indeed, the selection coefficient associated with participation in the employment program is negative and significant. This result reflects the fact that the characteristics that encourage participation in the employment program have an effect on employability. 
Table 5. Results of the ordered logit model and marginal effects after estimating the employability equation.

\begin{tabular}{|c|c|c|c|c|c|}
\hline \multirow{2}{*}{\multicolumn{2}{|c|}{ Variables Coefficient }} & \multicolumn{4}{|c|}{ Marginal Effets } \\
\hline & & (1) & (2) & (3) & (4) \\
\hline Age & $\begin{array}{l}0.198^{\star} \\
(0.081)\end{array}$ & $\begin{array}{l}-0.007 \\
(0.004)\end{array}$ & $\begin{array}{l}-0.002 \\
(0.001)\end{array}$ & $\begin{array}{c}0.001 \\
(0.000)\end{array}$ & $\begin{array}{c}0.008 \\
(0.004)\end{array}$ \\
\hline Age2 & $\begin{array}{c}-0.321^{\star *} \\
(0.148)\end{array}$ & $\begin{array}{l}0.009^{* *} \\
(0.004)\end{array}$ & $\begin{array}{l}0.002^{\star *} \\
(0.001)\end{array}$ & $\begin{array}{c}-0.001^{\star *} \\
(0.000)\end{array}$ & $\begin{array}{c}-0.010^{\star *} \\
(0.004)\end{array}$ \\
\hline Marital Status & \multicolumn{5}{|c|}{ Ref: Single } \\
\hline Common-law union & $\begin{array}{l}-0.119 \\
(0.128)\end{array}$ & $\begin{array}{c}0.017 \\
(0.019)\end{array}$ & $\begin{array}{c}0.004 \\
(0.004)\end{array}$ & $\begin{array}{l}-0.001 \\
(0.001)\end{array}$ & $\begin{array}{l}-0.020 \\
(0.022)\end{array}$ \\
\hline Separated & $\begin{array}{c}1.359^{\star * *} \\
(0.508)\end{array}$ & $\begin{array}{c}-0.151^{\star * *} \\
(0.041)\end{array}$ & $\begin{array}{c}-0.061^{\star * *} \\
(0.025)\end{array}$ & $\begin{array}{c}-0.030^{\star * *} \\
(0.023)\end{array}$ & $\begin{array}{c}0.242^{\star * *} \\
(0.087)\end{array}$ \\
\hline Divorced & $\begin{array}{c}0.55 \\
(0.89)\end{array}$ & $\begin{array}{l}-0.072 \\
(0.105)\end{array}$ & $\begin{array}{l}-0.022 \\
(0.040)\end{array}$ & $\begin{array}{l}-0.004 \\
(0.016)\end{array}$ & $\begin{array}{c}0.097 \\
(0.161)\end{array}$ \\
\hline Widow(er) & - & - & - & - & - \\
\hline Married & $\begin{array}{c}1.788 \\
(0.268)^{\star * \star}\end{array}$ & $\begin{array}{c}0.303 \\
(0.047)\end{array}$ & $\begin{array}{c}0.005 \\
(0.008)\end{array}$ & $\begin{array}{l}-0.070 \\
(0.016)\end{array}$ & $\begin{array}{l}-0.239 \\
(0.026)\end{array}$ \\
\hline Training Area & \multicolumn{5}{|c|}{ Ref: General training } \\
\hline Technical training & $\begin{array}{l}1.681^{\star * *} \\
(0.115)\end{array}$ & $\begin{array}{c}-0.249^{* * *} \\
(0.016)\end{array}$ & $\begin{array}{c}-0.052^{* * *} \\
(0.005)\end{array}$ & $\begin{array}{c}0.018^{\star * * *} \\
(0.005)\end{array}$ & $\begin{array}{c}0.283^{\star * * *} \\
(0.016)\end{array}$ \\
\hline Household size & $\begin{array}{c}-0.01 \\
(0.006)\end{array}$ & $\begin{array}{c}0.001 \\
(0.001)\end{array}$ & $\begin{array}{c}0.000 \\
(0.000)\end{array}$ & $\begin{array}{l}-0.000 \\
(0.000)\end{array}$ & $\begin{array}{l}-0.002 \\
(0.001)\end{array}$ \\
\hline Environment & \multicolumn{5}{|c|}{ Ref: Pointe-Noire } \\
\hline Brazzaville & $\begin{array}{c}0.176 \\
(0.142)\end{array}$ & $\begin{array}{l}-0.026 \\
(0.021)\end{array}$ & $\begin{array}{l}-0.005 \\
(0.004)\end{array}$ & $\begin{array}{c}0.002 \\
(0.002)\end{array}$ & $\begin{array}{c}0.030 \\
(0.024)\end{array}$ \\
\hline $\begin{array}{c}\text { Distance entre betwee } \\
\text { your home and the } \\
\text { employment office }\end{array}$ & \multicolumn{5}{|c|}{ Ref: less than $500 \mathrm{~m}$} \\
\hline $500 \mathrm{~m}-1 \mathrm{~km}$ & $\begin{array}{c}-0.51 \\
(0.553)\end{array}$ & $\begin{array}{c}0.077 \\
(0.082)\end{array}$ & $\begin{array}{c}0.017 \\
(0.021)\end{array}$ & $\begin{array}{l}-0.007 \\
(0.009)\end{array}$ & $\begin{array}{l}-0.088 \\
(0.097)\end{array}$ \\
\hline $1 \mathrm{~km}-2 \mathrm{~km}$ & $\begin{array}{l}-0.862 \\
(0.516)\end{array}$ & $\begin{array}{c}0.137 \\
(0.077)\end{array}$ & $\begin{array}{c}0.024 \\
(0.019)\end{array}$ & $\begin{array}{l}-0.018 \\
(0.011)\end{array}$ & $\begin{array}{l}-0.143 \\
(0.089)\end{array}$ \\
\hline $2 \mathrm{~km}-4 \mathrm{~km}$ & $\begin{array}{c}-0.554^{\star} \\
(0.478)\end{array}$ & $\begin{array}{l}0.084^{*} \\
(0.068)\end{array}$ & $\begin{array}{l}0.019^{*} \\
(0.019)\end{array}$ & $\begin{array}{c}-0.008^{\star} \\
(0.005)\end{array}$ & $\begin{array}{c}-0.095^{\star} \\
(0.085)\end{array}$ \\
\hline $4 \mathrm{~km}-8 \mathrm{~km}$ & $\begin{array}{l}-0.513 \\
(0.464)\end{array}$ & $\begin{array}{c}0.078 \\
(0.065)\end{array}$ & $\begin{array}{c}0.018 \\
(0.019)\end{array}$ & $\begin{array}{l}-0.007 \\
(0.003)\end{array}$ & $\begin{array}{l}-0.089 \\
(0.084)\end{array}$ \\
\hline $8 \mathrm{~km}-16 \mathrm{~km}$ & $\begin{array}{l}-0.358 \\
(0.463)\end{array}$ & $\begin{array}{c}0.053 \\
(0.065)\end{array}$ & $\begin{array}{c}0.013 \\
(0.019)\end{array}$ & $\begin{array}{l}-0.003 \\
(0.002)\end{array}$ & $\begin{array}{l}-0.063 \\
(0.084)\end{array}$ \\
\hline More than $16 \mathrm{~km}$ & $\begin{array}{l}0.383 \\
(0.47)\end{array}$ & $\begin{array}{l}-0.049 \\
(0.065)\end{array}$ & $\begin{array}{l}-0.018 \\
(0.020)\end{array}$ & $\begin{array}{l}-0.004 \\
(0.002)\end{array}$ & $\begin{array}{c}0.071 \\
(0.085)\end{array}$ \\
\hline
\end{tabular}




\section{Continued}

\begin{tabular}{|c|c|c|c|c|c|}
\hline Migration & & & Ref: No & & \\
\hline Yes & $\begin{array}{c}0.031 \\
(0.118)\end{array}$ & $\begin{array}{l}-0.005 \\
(0.017)\end{array}$ & $\begin{array}{l}-0.001 \\
(0.004)\end{array}$ & $\begin{array}{c}0.000 \\
(0.001)\end{array}$ & $\begin{array}{c}0.005 \\
(0.020)\end{array}$ \\
\hline Employment program & \multicolumn{5}{|c|}{ Ref: No participant } \\
\hline Participant & $\begin{array}{c}-1.331^{\star * *} \\
(0.26)\end{array}$ & $\begin{array}{c}0.197^{\star * *} \\
(0.037)\end{array}$ & $\begin{array}{c}0.041^{\star * *} \\
(0.009)\end{array}$ & $\begin{array}{c}-0.014^{\star * *} \\
(0.004)\end{array}$ & $\begin{array}{c}-0.224^{\star * *} \\
(0.043)\end{array}$ \\
\hline $\mathrm{Pmr}$ & $\begin{array}{c}-8.341^{* * *} \\
(0.586)\end{array}$ & $\begin{array}{c}1.233^{\star * *} \\
(0.076)\end{array}$ & $\begin{array}{c}0.258^{\star * *} \\
(0.026)\end{array}$ & $\begin{array}{c}-0.088^{\star * *} \\
(0.022)\end{array}$ & $\begin{array}{c}-1.403^{\star * *} \\
(0.087)\end{array}$ \\
\hline _cut1 & $\begin{array}{l}-2.062 \\
(0.734)\end{array}$ & & & & \\
\hline _cut2 & $\begin{array}{l}-1.023 \\
(0.732)\end{array}$ & & & & \\
\hline _cut3 & $\begin{array}{c}0.17 \\
(0.732)\end{array}$ & & & & \\
\hline $\mathrm{N}=1.385 . \mathrm{LR}$ chi 2 & $\begin{array}{l}=583.56 . \\
\text { Log pseudo }\end{array}$ & $\begin{array}{l}\text { ob > chi2: } \\
=-1578.9\end{array}$ & $.000 . p s e$ & lo $\mathrm{R}^{2}=0.15$ & \\
\hline
\end{tabular}

Notes: SE in brackets $/{ }^{* *} p<0.01 .{ }^{\star *} p<0.05 .{ }^{\star} p<0.1$. Source: Elaborated from data from EAPE-C (2018).

Overall, the analysis of Graph 1 shows a better discrimination for the model. Indeed, we can see that the curve deviates from the bisector and the air of the surfaces is between 0.7 and 0.9 . This situation raises the quality of the estimated model.

To this end, the analysis of the estimation results will be organized into two points. The first point will discuss the determinants of participation in employment programs and the second point will discuss the effects of employment policies on employability.

\section{- Determinants of participation in employment programs}

Analysis of the results in Table 4 shows that gender, age, marital status, religion, and enrollment in ONEMO in affect on the participation of youth in employment programs. Indeed, the results reveal that the above variables are significant at the $10 \%$ level.

With regard to the variable gender, the results obtained show that men are more likely to participate in public employment programs than are women. This result can be explained by the importance of the unemployment rate at the level of men (29\%) than at the level of women (24\%), as revealed by the results of the EAPE-C (2018). Moreover, while age has positive and significant effects on the probability of participating in an employment program, this probability increases at a decreasing rate. That is, all else is equal, if age increases by one year, then the probability of participating in the employment program increases to a level at which the probability becomes negative. These results confirm those obtained by Attanasio et al. (2015) in Colombia and Ndinga et al. (2020) in the Congo, who showed that the effectiveness of employment programs is greater for women than for men. 


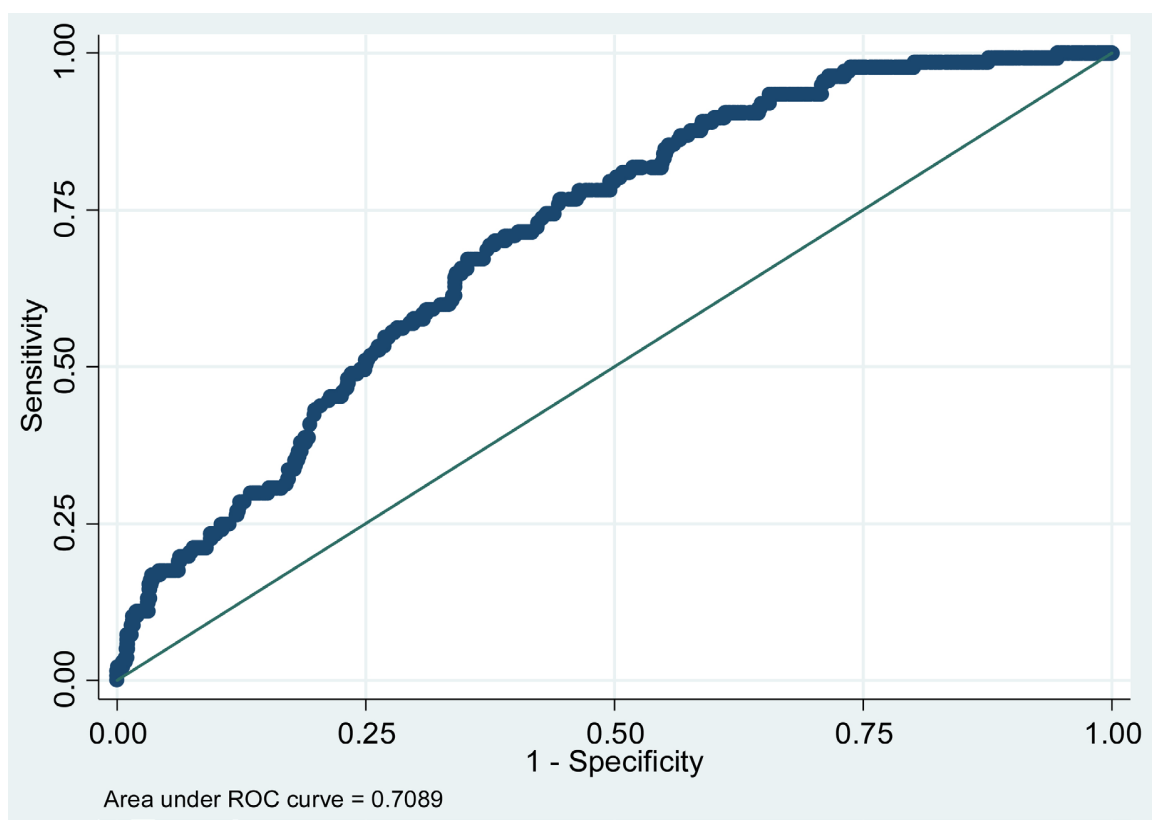

Graph 1. Roc curve. Source: Elaborated from data from EAPE-C (2018).

Regarding the knowledge of agencies (registration with ONEMO), it appears that being registered with ONEMO reduces the probability of participating in employment programs compared to those who do not know about ONEMO. This result in the case of the Republic of the Congo can be explained in part by the importance of social capital in the labor market (EAPE-C, 2018). This result confirms, to some extent, the results of the work of N'guessan (2015) in Côte d'Ivoire and Ouadika and Sah (2019), who highlighted the use of family networks in the search.

The estimation of the ordered logit model also allows us to identify the marginal effects of the explanatory variables for each modality, i.e., for each level of employability. These marginal effects are shown in columns (1), (2), (3) and (4) Table 5. The interpretation of these effects focuses on our variable of interest, namely participation in the employment program. Indeed, the calculated marginal effects indicate that all other things being equal, participation in an employment program improves the probability of an individual having very low employability by $19.7 \%$ and low employability by $4.1 \%$. However, it appears that this influence decreases as one move toward high employability by $22.4 \%$. The results obtained suggest that participation in the employment program improves the employability of young people in the Republic of the Congo. This result gives rise to a few comments. First, there is the problem of the effectiveness of employment policies in the Republic of the Congo. Indeed, since the early 2000s, the Republic of the Congo has initiated and implemented several public employment programs; these programs have enabled the integration of six thousand four hundred and forty-seven (6447) young people (EAPE-C, 2018). These results are consistent with those obtained by Kane (2019) in Senegal. Similarly, the studies of Fox and Kaul (2017); Kluve et al. (2017) and Ndinga et al. (2020) 
have shown that participation in an employment program promotes access to employment for young people.

Second, the problem of the limited effects of employment programs, is that although they have positive effects on employability, these effects are limited. These results can be explained by the low use of public employment services, only approximately $3.2 \%$ of unemployed individuals make use of public employment services (PND/DSCERP, 2012-2016). To this issue, we add the problem of the level of education and training areas of the candidates. These results can be explained by the phenomenon of the mismatch between the education system and the labor market, thus highlighting the importance of public employment policies and the education system (EAPE-C, 2018). These results are confirmed by the work of Dufour \& Frimousse (2006). Similarly, the work of Kloman-Kouakou et al. (2020) in Côte d'Ivoire and Ndinga (2020) and Ngassa (2018) in the Republic of the Congo has shown that social capital favor obtaining a job.

\section{Conclusion and Policy Implications}

The objective of this article was to analyze the effects of public employment policies on the employability of young people in the Republic of the Congo. Thus, to achieve our objective three steps were followed.

The first stage consisted of a theoretical review of the effects of public employment policies on the employability of young people. To this end, the different related theories were reviewed. This task highlighted three main approaches: 1) the approach based on the idea that public employment policies increase the ability to obtain employment for beneficiaries through the improvement of employability (Charlot, 2005); 2) the approach based on the hypothesis that public employment policies develop the spirit of entrepreneurship for the beneficiaries and 3) the third approach revolves around the hypothesis of job creation.

The approach revolves around the idea that public employment policies increase the ability of beneficiaries to obtain a job through improved employability (Charlot, 2005).

In the second stage of this article, a composite indicator of young people's employability is constructed on the basis of the various dimensions selected (Finot, 2000; Roger, 2004; Hillage \& Pollard, 1999).

Finally, in the third step, this article used an ordered logit model with a correction for selection bias to analyze the effects of public employment policies on employability. From the results obtained after the estimation, we can suggest the following:

1) Participation in the employment program improves the employability of young in the Republic of the Congo, but its effects are limited. This result confirms the fact that human capital is a source of income improvement.

2) Variables such as gender, age, marital status, religion, and ONEMO registration, influence participation in employment programs in the Republic of the 
Congo.

In view of these results, it appears that the public employment policies that have been implemented to promote youth employment in the Congo are effective since they are shown to improve the employability of young people with a low level of employability, however, their effects are limited in regard to solving the problem of unemployment. To this end, the state, in collaboration with private sector employers, should encourage and sustain these policies to considerably reduce unemployment in the Congo. Since knowledge of the agency influences participation in employment programs, the state should develop a system aimed at raising awareness of employment agencies among beneficiaries.

\section{Conflicts of Interest}

The authors declare no conflicts of interest regarding the publication of this paper.

\section{References}

Adams (2017). The Sustainable Development Goals, Integrated Thinkingand the Inte grated Report. $20 \mathrm{p}$.

http://integratedreporting.org/wp-content/uploads/2017/09/SDGs-and-the-integratedreport_17.pdf

African Development Bank (2018). Country Strategy Paper 2018-2022 for Republic of the Congo. $84 \mathrm{p}$.

African Economic Outlook (2018). https://www.afdb.org/fileadmin/uploads/afdb/Documents/Publications/African_Econom ic_Outlook_2018_-_FR.pdf

Attanasio, O., Guarín, A., Medina, C., \& Meghir, C. (2015). Long-Term Impacts of Vouchers for Vocational Training: Experimental Evidence for Colombia. SSRN.

Becker, G. S. (1964). A Theory of Social Interactions. Journal of Political Economy, 82, 1063-1091. https://doi.org/10.1086/260265

Becker, G. S. (1964). Human Capital: A Theoretical and Empirical Analysis, with Special Reference to Education. University of Chicago Press.

Béduwé, C., \& Mora, V. (2017). From the Professionalism of Students to Their Employability, Is There Only on Step? Formation Emploi, 138, 59-77.

Ben Hassen, N. (2011). Le développement de l'employabilité dans les organisations: Une aide à la rénovation de gestion des ressources humaines et à l'accroissement de performances économiques et sociales: Cas d'entreprises industrielles tunisiennes. Conservatoire National des Arts et Metiers (CNAM). https://tel.archives-ouvertes.fr/tel-00651487

Cahuzac, E., \& Détang-Dessendre, C. (2008). Une part croissante dans l'emploi des exploitations mais une précarité des statuts. Économie Rurale, 323, 82-92.

Cart, B., \& Toutin, M. H. (1996). Adaptabilité, transférabilité de la compétence et expérience professionnelle. Cahiers Lillois d'Économie et de Sociologie (CLÉS), No. 27, 5-16.

Chapple, S., Harris, R., \& Silverstone, B. (1996). Unemployment. In B. Silverstone, A. Bollard, \& R. Lattimore (Eds.), A Study of Economic Reform: The Case of New Zealand (pp. 139-172). Elsevier Science. 
Charlot, B. (2005). Le Rapport au Savoir en milieu populaire. Une recherche dans les lycées professionnels de banlieue. Revue Française de Pédagogie, N¹31, 136-138.

Crépon, B., Duflo, E., Gurgand, M., Rathelot, R., \& Zamora, P. (2013). Do Labor Market Policies Have Displacement Effects? Evidence from a Clustered Randomized Experiment. Quarterly Journal of Economics, 128, 531-580. https://doi.org/10.1093/qje/qjt001

Deci, E. L., \& Ryan, R. M. (1995). Human Autonomy: The Basis for True Self-Esteem. In M. Kemis (Ed.), Efficacy, Agency and Self-Esteem (pp. 31-49). Springer. https://doi.org/10.1007/978-1-4899-1280-0_3

Dubin, J. A., \& McFadden, D. L. (1984) An Econometric Analysis of the Residential Electric Durable Good Holdings and Consumption. Econometrica, 52, 345-362. https://doi.org/10.2307/1911493

Dufour, L., \& Frimousse, S. (2006). La socialisation organisationnelle des jeunes à faible capital scolaire. Management Prospective, No. 10, 145-160.

EAPE-C (2018). L'Enquête sur l'Amélioration des Politiques d'Emploi au Congo. EAPE-C.

Finot, A. (2000). Développer l'employabilité. INSEP CONSULTING.

Fluitman, F. (1989). Training for Work in the Informal Sector. Bureau International du Travail.

Fox, L., \& Kaul, U. (2017). The Evidence Is in: How Should Youth Employment Programs in Low Income Countries Be Designed? USAID.

Gasquet, C. S. (2002). Une évaluation économétrique de l'impact des politiques publiques d'emploi sur les trajectoires professionnelles des demandeurs d'emploi.

Granovetter, M. S. (1973). The Strength of Weak Ties. American Journal of Sociology, 78, 1360-1380. https://doi.org/10.1086/225469

Hicks, J. R. (1932). The Theory of Wages (2nd ed.). MacMillan and Co.

Hillage, J., \& Pollard, E. (1999). Employability: Developing a Framework for Policy Analysis. DFEE Publications.

ILO (2014). Global Employment Trends 2014: Risk of a Jobless Recovery? ILO.

ILO (2019). 2019 Annual Report. ILO.

ILO (2020). World Employment and Social Issues Trends 2020. ILO.

Issehnane, S. (2009). Les politiques publiques d'insertion professionnelle des jeunes: La France peut-elle s'inspirer des expériences étrangères? Revue Interventions Économique, 40, 1-75. https://doi.org/10.4000/interventionseconomiques.98

Jérome, G., Bernard, G., \& Rachel, S. (1994). Quelques expériences européennes de subvention à l'emploi. La Documentation Française, 59, 101-107.

Julhe, S., \& Marina, H. (2012). L'articulation travail-famille chez les conseillers techniques sportifs: Situations asymétriques entre hommes et femmes. Sociologie, 3, 341-357.

Kalton, G. (1983). Introduction to Survey Sampling. Sage Publication, 96 p. https://doi.org/10.4135/9781412984683

Kane, A. (2019). Efficacité des politiques de promotion de l'emploi des jeunes au Sénégal. 17 Pages Document de Recherche.

Kasekende, L., \& Brownbridge, M. (2011). Post-Crisis Monetary Policy Frameworks in Sub-Saharan Africa. African Development Review, 23, 190-201. https://doi.org/10.1111/j.1467-8268.2011.00280.x

Kloman-Kouakou et al. (2020). Capital social, employabilité et qualité de l'emploi des jeunesdiplômésen Côte d'Ivoire. Revue ivoirienne de Sciences et de Gestion, No. 1, 61-86.

Kluve, J., Puerto, S., Robalino, D., Romero, J. M., Rother, F., Stoterau, J., Weidenkaff, F., 
\& Witte, M. (2017). Interventions to Improve Labour Market Outcomes of Youth: A Systematic Review. Campbell Systematic Reviews, 13, 1-288.

Kolev, A., Filipiak, E. et al. (2010). Gender Disparities in Africa's Labor Market. Agence Française de Développement and the World Bank.

Kouakou, C. K. (2011). Urban Youth Labour Supply and Employment policy in Côte d'Ivoire. AERC Research Paper.

Loufrani-Fedida, S., Oiry, E., \& Saint-Germes, È. (2015). Vers un rapprochement de l'employabilité et de la gestion des compétences: Grille de lecture théorique et illustrations empiriques. Revue de Gestion des Ressourceshumaines, N97, 17-38.

Maddala, G. S. (1983). Limited-Dependent and Qualitative Variables in Econometrics. Cambridge University Press. https://doi.org/10.1017/CBO9780511810176

Magnac, T. (1997). Les stages et l'insertion professionnelle des jeunes: Une évaluation statistique. Economie et Statistique, No. 304-305, 75-94.

https://doi.org/10.3406/estat.1997.2557

Magnac, T. (2000). L'apport de la microéconométrie à l'évaluation des politiques publiques. Cahiers d'Économie et Sociologie Rurales, N54, 89-113.

Makosso, B. (2013). L'entrepreneuriat dans un contexte d'adversité: Une analyse des déterminants macroéconomiques de la création de nouvelles entreprises au Congo Brazzaville. Revue de l'Entrepreneuriat, 12, 11-31.

Meyer, J. B., \& Charum, J. (1995). La “fuite des cerveaux" est-elle épuisée? Paradigme perdu et nouvelles perspectives. Cahiers des Sciences Humaines, 31, 1003-1017.

N'Guessan, C. F. J. (2015). Analyse des déterminants de l'intensité de la recherche d'emploi en Côte d'Ivoire. L'Actualité Économique: Revue d'Analyse Économique, 91, 339-366. https://doi.org/10.7202/1036494ar

Ndinga, M. M. A. (2020). Impact des politiques publiques d'emploi sur la sortie du chômage des jeunes au Congo. 32 Pages Document de Recherche.

Ngassa, T. C. (2018). Effets du capital social sur l'accès à l'emploi au Congo. Thèse de Doctorat, Faculté des Sciences Économiques, Université Marien Ngouabi.

Ouadika, S. A. B. \& Sah, R. (2019). Profils des jeunes et recherche d'emploi au Congo. 21 Pages Document de Recherche.

Pigou, A. C. (1933). The Theory of Unemployment. Routledge. https://doi.org/10.4324/9780203041536

Pnd/Dscerp (2012-2016). Plan National de Développement du Congo. Document de Stratégie pour la Croissance, l'Emploi et la Réduction de la Pauvreté 2016.

Roger, H. (2004). Gérer l'employabilité des salariés: Gérer un avantage concurrentiel et une performance durable à l'entreprise. In Actes (Ed.), 15e Congrès de l'AGRH (pp. 1694-1718). Montréal.

Saint-Germes, E (2004). L'employabilité, une nouvelle dimension pour la GRH? Actes du $X V e$ Congrès de l'AGRH (pp. 1888-1906). Montréal.

Saloua, Z. et al. (2016). Les pratiques de gestion des resources humainesenfaveur du développement de l'employabilité. Revue Management \& Avenir, No. 90, 15-37.

Samuel et al. (2012). L'articulation travail-famille chez les conseillers techniques sportifs: situations asymétriques entre hommes et femmes. Presses Universitaires de France, 3, 341-357. https://doi.org/10.3917/socio.034.0341

Spierings, C. H. B. M., Smits, J. P. J. M., \& Verloo, M. (2008). Micro and Macro Level Determinants of Women's Employment in Six MENA Countries. NiCE Working Paper 08-104. 
Thiaw, M. (2020). Politiques d'emploi des jeunes et qualifications sur le marché du travail: Cas du Sénégal. Revue Africaine de Management, 5, 137-155.

Torns, T. (1995). Chômages. In Ephésia (Ed.), La place des femmes, les enjeux de l'identité et de l'égalité au regard des sciences sociales (pp. 529-533). La Découverte.

Valérie, K. K. et al. (2020). Capital Social, employabilité et qualité de l'emploi des jeunes diplômés en Côte d'Ivoire. Revue Ivoirienne de Sciences et de Gestion, No. 1, 65-86.

Van Der Heijden, C. M., \& Van Der Heijden, B. (2006). A Competence-Based and Multidimensional Operationalization and Measurement of Employability. Human Resource Management, 45, 449-476.

Wohlmuth, K. et al. (2021). Sustainable Development Goal Nine (SDG 9) Approches Relatives à une stratégie nationale pour l'emploi en Tunisie. ÉTUDE, 17 p.

Zgoulli, S. et al. (2016). Les pratiques de gestion des resources humainesenfaveur du développement de l'employabilité. Management Avenir, No. 90, 15-37.

https://doi.org/10.3917/mav.090.0015 